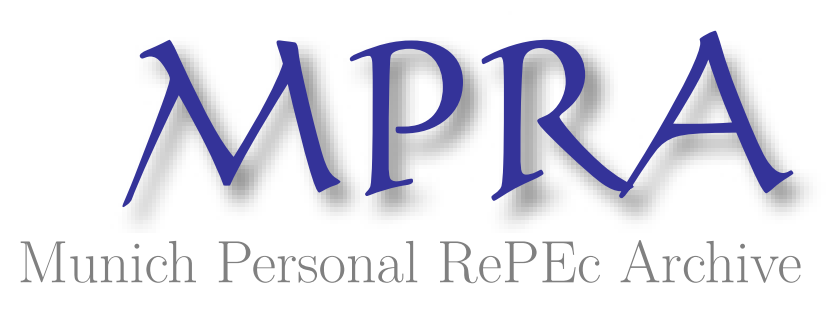

\title{
Fair value accounting in banking - Issues in convergence to IFRS
}

Swamy, Vighneswara

2010

Online at https://mpra.ub.uni-muenchen.de/40881/

MPRA Paper No. 40881, posted 05 Sep 2014 07:19 UTC 


\section{FAIR VALUE ACCOUNTING IN BANKING - ISSUES IN CONVERGENCE TO IFRS}

By

Dr. Vighneswara Swamy* and Dr. Vijayalakshmi**

*Dr. Vighneswara Swamy is currently working as Asst. Professor at IBS-Hyderabad. He is reachable at vighneswar@ibsindia.org Phone: +91-9705096919.

** Dr. Vijayalakshmi is currently working as Associate professor at IBS-Hyderabad. She is reachable at vijayas@ibsindia.org Phone:+91-9246284374 


\title{
FAIR VALUE ACCOUNTING IN BANKING - ISSUES IN CONVERGENCE TO IFRS
}

\begin{abstract}
This paper intends to analyse and elucidate the impact of Fair Value Accounting on the banking industry in general and Indian Banking in particular in the light of the move towards convergence to International Financial Reporting Standards across the globe. In the light of criticism against fair value accounting for amplifying the subprime crisis and for causing a financial meltdown, the article has analysed the nature and impact of Fair Value Accounting in view of the recent announcement of the Indian version of IFRS i.e Ind $A S$ by the regulators in India and its impact in relation to the contentious issues like; systemic risk, contagion and its impact on investors. Further, the article highlights the areas in which Indian banking industry is required to focus before and after the implementation of Fair Value Accounting and their consequences on the financial statements of the Bank.
\end{abstract}

Keywords: $\quad$ IFRS, Banking, Convergence of IFRS, Financial reporting, Investment, Capital, Banking

JEL Classification: $\quad E$ 22, $M 41, G 24$ 


\section{INTRODUCTION}

Introduction of a comprehensive Fair Value Accounting framework for the recognition and measurement of financial instruments has been a long term strategy of International Accounting Standards Board (IASB). Accordingly, there has been a steady emphasis on the extensive use of a "Fair Value" (FV) as the basis for the valuation of all financial instruments in a bank's balance sheet. Fair Value Accounting (FVA) (also known as mark-to-market accounting) has been around for decades, but the methods for calculating fair value were inconsistent. In 2006 - in response to investors' need for consistent, relevant and timely financial information — the Financial Accounting Standards Board (FASB) adopted Statement No. 157 which established consistent criteria for assessing fair value in various market conditions. Fair Value Accounting is a debate that has raged for months among auditors, bankers, pundits and politicians. Of course finding a solution to please one and all has proven difficult. Over $\$ 350$ billion of write-downs and losses by the banks in the United States during the crisis has indeed led to confusion and uncertainty to reign. Given this background, there is a need for all the stake holders to gain a clear understanding of the perspectives revolving around this contentious issue.

\section{FAIR VALUE ACCOUNTING}

Mark-to-market accounting, a regulation which mandated the US banks to bear more securities at market value, owes its genesis to the US savings and loan crisis when losses on loans were concealed by the use of "historic cost" accounting. Even though FVA has been a part of GAAP since the early 1990s, the use of fair value measurements has enlarged steadily over 
the past decade largely in response to investor demand for pertinent and apt financial statements that will aid them in making better investment decisions.

Fair value, also called fair price is a concept used in accounting and economics. 'Fair Value' is defined $^{1}$ as "a rational and unbiased estimate of the potential market price of a good, service, or asset, taking into account objective factors such as; (a) acquisition/production/distribution costs, replacement costs, or costs of close substitutes, (2) actual utility at a given level of development of social productive capability and (3) supply vs. demand and subjective factors such as; risk characteristics, cost of and return on capital and individually perceived utility". FAS 157 defines 'fair value' as "the price that would be received to sell an asset or paid to transfer a liability in an orderly transaction between market participants at the measurement date." Further, 'Fair value ${ }^{, 2}$ is defined similarly under IFRS as "the amount for which an asset could be exchanged, or a liability settled, between knowledgeable, willing parties, in an arm's length transaction”. While estimating the fair value, IFRS makes comparable distinctions among inputs as FAS 157: Quoted prices in active markets must be used as fair value when available. In the absence of such prices, an entity must use valuation techniques and all pertinent market information that is accessible so that valuation techniques maximize the use of observable inputs (IAS 39). It is established that an entity might have to make significant adjustments to an observed price in order to arrive at the price at which an orderly transaction would have taken place (IASB Expert Advisory Panel, 2008). Under both U.S. GAAP and IFRS, fair values are most frequently used for financial assets and liabilities.

\footnotetext{
${ }^{1}$ As defined in Wikipedia (www.wikipedia.org)

${ }^{2}$ For a good quality reference on Fair value it is suggested to refer Barth (2004), Penman (2007), Benston (2008) and Ryan (2008).
} 
According to FVA, the assets and liabilities of banks are carried in the balance sheet at Market Values, if they are available, or at fair values estimated as an approximation of the market value by using a Present Value model for discounting the expected future cash flow. For banks, this would imply that the trading and banking books would receive equal accounting treatment, whereby all changes in value would have to be captured in the balance sheet and transferred to the profit and loss account. The foreseen revaluation is applicable irrespective of whether a profit or loss has been recognized or remains un-realised since all instruments are either marked to market or the fair value is calculated. The cloaked reserves that might arise under the existing accounting rules thus disappear. Thus, under FVA framework, Market risks would be reckoned during the calculation of the value of financial instruments in both the trading and the banking book.

The proponents of FVA state that, from a conceptual point of view, FVA regime constitutes a realistic approach to financial performance reporting in order to avoid some of the problems associated with the current historical cost accounting. One of the advantages of FVA regime would be to augment the degree of transparency of financial statements. On the other hand, this point of view continues to be theoretical due to the absence of homogeneity and comparability in FVA methodologies. In addition, the possible concrete application of a full FVA regime (applying to all assets and liabilities) to the banking sector gives rise to some problems and concerns.

Applicability of FVA is opined to be in the case of the trading book of banks, which refers to transactions (buying and selling) of marketable securities and related instruments with 
the rationale of making a profit from short-term price variations. Making use of FVA for these transactions is steadfast with the availability of market prices and the short-term horizon. Nevertheless, its use in the case of the banking book of banks, i.e. to non-negotiable instruments such as loans, comes out to be out of place. On the other hand, the IAS 39 "Financial Instruments: Recognition and Measurement", has already broadened the use of fair value in relation to the banking book by compelling the fair value revaluation of assets available for sale.

\section{FVA DEBATE}

The Financial Accounting Standards Board (FASB) states that its long-term objective of accounting for financial instruments is to employ 'fair value' to measure and report financial instruments (Statement of Financial Accounting Standard (SFAS) No. 159). Proponents of FVA argue that fair values for assets or liabilities reflect current market conditions and hence provide timely information, thereby increasing transparency and encouraging prompt corrective actions. However, FVA is blamed by several quarters of the business accounting world for amplifying the Subprime Crisis and the resultant Global Financial Crisis, which is considered by many as the worst economic crisis in the United States since the Great Depression (Ryan 2008). A report by the Office of the Chief Accountant of the SEC for the Congressional committee (SEC 2005) in United States (US) states that there are two primary benefits of using FVA. First, employing FVA would moderate the accounting-motivated transactions premeditated to manipulate the earnings under the current "mixed attribute" accounting model (which is partly at "historical cost" and partly at "fair value"), i.e., opportunity to engage in "gains trading" can be avoided to a considerable extent. Second, financial statements developed by employing FVA framework

\footnotetext{
3 'Gains trading' refers to the practice of selling appreciated securities to recognize gains while securities with unrealized losses are held to avoid recognizing those losses (SFAS No. 115).
} 
would be less complex relative to the ones currently prepared under the 'mixed attribute' model. Landsman (2006) observes that with all financial instruments measured at fair value, the 'hedge accounting' model employed by SFAS No. 133 would be eliminated. And hence, investors would no longer need to study the choices made by management to ascertain what basis of accounting is used for particular instruments and at the same time the firm would no longer need to maintain records of the hedging relationships.

Some financial institutions argue that FVA compels them to write down certain financial assets to a level below the value they expect to recover in the long term, thus, gripping them to curtail lending activities and conserve the capital solely to comply with the relevant regulatory requirements. Other stakeholders, including investors and auditors, believe that properly applied FVA provides the most transparent picture of the relative financial condition of an organization, thereby facilitating the allocation of investment capital to the best performers. Few argue that transparency is very vital. But the contention rests on whether FVA in reality is helpful in providing transparency and whether it leads to adverse actions on the part of banks and firms. Opponents to FVA claim that "fair value" is not relevant and potentially misleading for assets that are held for a long period and, in particular, to maturity. They argue that prices could be distorted by market inefficiencies, investor irrationality or liquidity problems. It is also curious to note that European banks seem more opposed to FVA than U.S banks. Contrary to the bankers' views, investor-interest groups and accountants are less worried about FVA, even in the current crisis, and counsel against a deferral of FVA. 
The current crisis has brought to the fore another issue that needs serious consideration, namely, FVA can cause pro-cyclicality. However, doing away with FVA and going back to historical accounting would not be the right option. Instead, capital adequacy and provisioning requirements could be made to take into account the cyclical effects of the economy by introducing higher provisions and higher capital adequacy during good times so that it would act as a cushion during bad times. Another option would be to increase the frequency of disclosures along with FVA, so that stakeholders are fully aware of the element of pro-cyclicality in the balance sheet of the banks. Further, carrying out stress tests based on fair values of the balance sheet and disclosing these results would make things easier (Report of CFSA, 2009).

\section{ISSUES IN FAIR VALUE ACCOUNTING}

In this section of the paper we would like to highlight some of the issues that need a thorough look in the implementation of FVA. These invite a detailed consideration on the part of the regulators before embarking upon the full scale implementation of FVA.

\section{Management Bias}

Managements use significant judgments during the valuation processes, which add to the concerns about reliability. Management Bias, be it deliberate or inadvertent, quite often would result in inappropriate fair value estimations and mis-statements of earnings and equity capital. Substantial write-downs of exaggerated asset valuations have caused the collapse of few finance companies and depository institutions. Problems akin to the above have also cropped up due to over-valuations in non-bank trading portfolios that resulted in over-statements of income and equity. 


\section{Reliability}

In case of liquid and transparent markets, for all assets and liabilities, FVA clearly would be reliable as the information available is rightly useful in the decision making process. However, as many assets and liabilities do not have active markets, the inputs and methods for evaluating their fair value are more discriminatory. The valuations, therefore, would be less dependable. We keep on seeing news stories about allegations of manipulation of earnings, even in the case of historical cost accounting framework too. In view of this, we can suppose that, in the absence of reliable fair value estimates, the prospects for mis-statements in financial statements will be even greater.

\section{Verification}

As the diversity and intricacy of financial instruments swell, so does the call for autonomous verification of fair value estimates. However, authentication of valuations that are not founded on discernible market prices is very demanding. But it is observed that many of the values would be based on information and technique chosen by management. Estimates based on these management opinions would likely be tricky to verify. Accordingly, auditors and other users of financial statements, like credit portfolio managers, would need to lay significant emphasis on appreciating how the assets and liabilities are calculated and how reliable are these valuations.

\section{Disclosures}

One of the arguments is that fair values reveal point estimates and they themselves, apparently, do not lead to transparency financial statements. Accordingly, further adequate 
disclosures are necessary to bring sagacity to these fair value estimates. Adequate disclosures should be well thought-out to provide users of financial statements a better appreciation of the reliability of fair value estimates. Such of the disclosures can include key drivers affecting the valuations, fair value range-estimates, and confidence levels. One more vital disclosure consideration is related to variations in fair value amounts. For instance, changes in fair values of securities portfolios can arise from the movements in foreign currency rates, interest rates, and also from the variations in credit quality, and also from purchases and sales from the portfolio. In order to make the users understand fair value estimates, we believe that, they have to be given enough disclosures as to what factors caused the variation in fair value.

\section{Credit Portfolio Management}

In a FVA framework, fair value estimates do affect the information one uses as credit portfolio manager. Nowadays, financial statements are guided by a 'mixed-attribute' model according to which an enterprises' balance sheet may include some values recorded as per historical cost and some others reported at fair value. Fair values may be employed as an analytical tool in the lending process and compared with historical cost values. It has to be understood that this historical cost information, along with coupled disclosures, enfolds dependable information that offers insights into an enterprise's expected cash flows. When the industry moves toward long-drawn-out use of fair value, we believe that disclosure of certain historical cost information would remain indispensable. 


\section{Bankers views on FVA during the crisis}

During the second half of 2008 when the crisis stepped up alarmingly, bankers raised concerns about FVA for any but the most liquid assets. They contended that FVA was the cause in aggravating the crisis by causing a downward spiral and hence market prices were significantly below the assets' fundamental values (US Bancorp, 2008, American Bankers Association, 2008 and Mortgage Bankers Association, 2008). Many prominent banks in U.S. and Europe demanded for a leeway in declaring the transactions disorderly and switching to models to determine fair values based on the underlying fundamentals or expected future cash flows (Institute of International Finance, 2008). Moreover, banks in Europe, demanded for the option

to reclassify financial instruments from the trading category to the held-to-maturity category [Tweedie, (2008) and Guerrera and Hughes, (2008)]. While this confrontation could be deemed as anecdotal evidence against FVA in financial crisis, the arguments could also be viewed as self-serving, essentially in passing on the blame for the crisis to the accounting standards.

\section{FVA and Systemic risk}

Cifuentes, Ferrucci, and Shin (2005) have, in an analytical framework, examined the effects of mark-to-market approaches of financial institutions' balance sheets when there are externally imposed regulatory solvency requirements. It is opined by them that, a shock that compresses the market value of assets carried on the balance sheets of financial institutions could lead to constrained disposal of assets in order to evade violation of solvency ratios. In such situations, in case, the capability of the market to absorb such sales is less than perfect (like that in a macroeconomic crisis) constrained disposals can extend to a further short-run fall in market prices. In view of this, under a mark-to-market accounting regime when assets are marked down 
to the new lower prices, banks could be forced to dispose of more assets to avoid violation of externally imposed prudential norms. Further continued disposal of assets can further lower the prices and could lead to a vicious loop of falling prices and continued asset disposals. Thus, it can be opined that the combination of mark-to-market accounting and externally imposed solvency restraints can lead to a downward spiral in asset prices and turn out to be a key source of systemic risk in the financial system.

\section{FVA and "Contagion" in the Banking Industry}

Some of the financial analysts contend that FVA exacerbated - or possibly even partly caused the recent global financial crisis. According to them, governmental regulations require banks to maintain capital adequacy ratio which is more or less owners' equity as a percentage of risky assets. When such asset values are marked down to fair values, regulatory capital becomes too low, forcing banks to convert some of their "risky" financial assets into "riskless" cash in order to boost the ratio described above. This could lead to a "fire sale" of assets, which would further lessen the market prices for these assets, causing further mark-to-market write downs by other banks, and the process starts afresh. In view of this, individual banks with a higher ratio of their assets marked to fair value experience greater exposure to this "contagion" effect.

\section{FVA and Underlying Financial and Economic Transactions}

An issue of consideration is whether fair value can accurately portray the underlying economic transactions. It is observed that when assets are valued employing internal value techniques there comes up the scope for misinterpretation or fraud (example being that of Enron). Fair value accounting can portray the market value of the assets accurately as it can 
adjust to the decrease and increase in the value of the asset whereas the historical cost accounting can only depreciate the value of an asset by ignoring the market value in the balance sheet. Historical cost accounting can capture the true value of the asset only when the asset is sold or traded.

\section{FVA and Investors}

Fair Value accounting offers the most transparent depiction of the financial condition of a company thereby enables the investors by facilitating the efficient allocation of investment capital to the performers. Protagonists of the FVA argue that writing down assets to market value offers investors a reliable picture of the current financial status of the company. Simply as the way banks require independent appraisal before making a loan, investors in the banks too have a right to know as to how the market values the financial assets of the bank. From the investors' point of view fair value accounting which brings in better transparency and objectivity in the financial reporting process is benign.

Several of the claims for and against fair value accounting are logical. In severe economic conditions — positive or negative — fair value accounting that depends immensely on topical sales prices will, at some time, price-in either irrational enthusiasm or irrational phobia. Put differently, the influence (real and psychological) of topical sales prices in these conditions will not reflect reasonable expected future cash flows. Highly leveraged companies--a phrase that labels most of Wall Street--might temper their risks if they know the assets they are taking on have to be marked to market value every day. It would be a warning for them to stay away from the extremely volatile assets. For some of the investment banks it would be a necessary 
evil. Some argue that, FVA has rather than making things plainer, it rules only point to the futility of pricing assets every day in highly volatile markets when the credit markets are frozen solid. The flip side to this is that it is unlikely, anyone would be complaining if asset values were rising and the markets weren't in crisis.

\section{INDIAN SCENARIO}

The objective of financial statements in the Indian context has been to provide information about the financial position, performance and cash flows that is practical in making right economic decisions. Corporate financial statements, with the notes and narratives surrounding them, are meant to enable investors to predict cash flows, find out returns generated on the capital invested, evaluate the business' liquidity, and estimate management's performance. A number of different mensurations are employed at various degrees and in varying grouping in financial statements which include the Historical Cost, Amortized Cost and Fair Value methods. The accounting norms for those assets and liabilities that are held at fair value are composite. Currently, in the case of commercial banks and some financial services firms, certain asset classes such as marketable equity securities and derivatives, are mandated to be passed at fair values. However, for other asset classes like debt securities, loan receivables, it depends on whether the assets are held for trading (active buying and selling) or held to maturity.

Financial Instruments constitute the bulk of banks' assets and liabilities and as IFRS requirements for accounting for financial instruments are prescriptive in nature this would lead to key implementation challenges. In the Indian context, adoption of IFRS has considerable 
significances on advances, Investments, financial instruments, hedge accounting valuation together with regulatory compliances, information technology systems, tax calculations and supplementary areas. Currently, different regulators like; Accounting Standards issued by Institute of Chartered Accountants of India (ICAI) and Reserve Bank of India (RBI) control bank accounting in India. IFRS 9 (Financial Instruments) has been issued and encompasses all financial assets. Standards relating to financial liability, impairment, derecognition and hedging are stated to be issued in a phased manner. Needless to say, the impact of IFRS 9 on banks will be significant. As India is on the path of IFRS adoption, Indian banks will have to closely examine the impact of IFRS 9 not only on their financial statements but also on their capital adequacy, IT systems, taxes and product design, among others.

In the area of financial instrument accounting the key differentiation between the recently released Ind AS 39 (Indian version of IFRS) and IAS 39 is found in the Measurement and Recognition of financial instruments. While IAS 39 requires all changes in fair values in financial liabilities to be recognised in profit or loss, Ind AS 39 stipulates determining the fair value of the financial liabilities, with initial recognition being designated at fair value through profit or loss, and any change in fair value thereafter consequent to changes in the entity's own credit risk shall be ignored. Further, Fair value according to Ind AS 39 is the amount for which an asset could be exchanged, or a liability settled, between knowledgeable, willing parties in an arm's length transaction. Relating to recognition and measurement, under Ind AS 39, the amortised cost of a financial asset or financial liability is the amount at which the financial asset or financial liability is measured at initial recognition minus principal repayments, plus or minus the cumulative amortisation using the effective interest method of any difference between that 
initial amount and the maturity amount, and minus any reduction (directly or through the use of an allowance account) for impairment or uncollectibility. Further, the effective interest method is a method of calculating the amortised cost of a financial asset or a financial liability (or group of financial assets or financial liabilities) and of apportioning the interest income or interest expense over the pertinent period. The effective interest rate being the rate that precisely discounts estimated future cash payments or receipts through the expected life of the financial instrument. Derecognition constitutes the deletion of a previously recognised financial asset or financial liability from an entity's balance sheet.

IFRS recognise the impairment model for the assets of the organization. However, the banking industry, at present recognizes the provisioning and writes off method for the valuation of its advances as per the prudential norms of Reserve bank of India. With regard to Impairment and uncollectibility of financial assets, Ind AS 39 states that an entity shall assess at the end of each reporting period whether there is any objective evidence that a financial asset or group of financial assets is impaired. According to it a financial asset or a group of financial assets is impaired and impairment losses are incurred if, and only if, there is an objective evidence of impairment as a result of one or more events that occurred after the initial recognition of the asset (a 'loss event') and that loss event (or events) has an impact on the estimated future cash flows of the financial asset or group of financial assets that can be reliably estimated. Whereas according to extant RBI guidelines banks consider provisions on loans, which are very prescriptive and require limited use of judgment. Whereas under Ind AS 39 impairment assessment system is based on all the facts and circumstances and necessitates the use of informed judgment. 
The Indian accounting standards are by and large aligned to the IFRS, though there are a few divergences. In India, we are yet to fully adopt the marking-to-market requirements as prevailing in the international standards. The Indian standards are comparatively conservative and do not allow recognition of unrealized gains in the profit and loss account or equity, though unrealized losses are required to be accounted. Banks are required to mark-to-market the investments in the Held for Trading (HFT) and Available for Sale (AFS) categories at periodical intervals, on a portfolio basis, and provide for the net losses and ignore the net gains. This indeed has proved to be a stabilizing factor, in as much as it has not induced an imbalance in the incentive structures and has also proved to be less pro-cyclical.

In an increasingly integrated and complex world market it is necessary that the Indian Banking System should compare its performance against the world benchmarks. Given this backdrop, Institute of Chartered Accountants of India announced that with effect from April 1, 2011 all listed and public sector entities should converge their reporting systems with IFRS. However, there is relief in store for Indian banks. According to Roadmap for Applicability of Converged Accounting Standards to Indian Companies issued recently by the Ministry of Company Affairs, Government of India, the cut-off date for implementation of Ind AS for the Scheduled Commercial Banks would be 1st April, 2013. There will be no concerns because the banking sector is anyway a part of Bank of International Settlements. All the pronouncements by the Bank of International Settlements are translated by the Reserve Bank and are made applicable in India. 
According to the recently released Indian Accounting Standard (Ind AS) 39 - Financial Instruments: Recognition and Measurement, by the Ministry of Company Affairs, Government of India, A financial asset or financial liability at fair value through profit or loss is a financial asset or financial liability that meets either of the following conditions; (i) It is classified as held for trading, (ii) Upon initial recognition it is designated by the entity as at fair value through profit or loss. According to Application Guidance (AG) 69 of Ind AS-39, underlying the definition of fair value is a presumption that an entity is a going concern without any intention or need to liquidate, to curtail materially the scale of its operations or to undertake a transaction on adverse terms. Fair value is not, therefore, the amount that an entity would receive or pay in a forced transaction, involuntary liquidation or distress sale. However, fair value reflects the credit quality of the instrument. Further, Ind AS 39 (AG72) states that the current bid price is usually the appropriate price to be used in measuring the fair value of an asset held. The best evidence of fair value is quoted prices in an active market. If the market for a financial instrument is not active, an entity establishes fair value by using a valuation technique.

Currently, banks in India follow the accounting norms of the Institute of Chartered Accountants of India (ICAI) and prudential norms of the Reserve Bank of India (RBI). To mention, Sub-group on addressing IFRS convergence implementation issues and formulation of operational guidelines relating to banks has indeed made some practicable recommendations. Probably, IFRS is expected to impact banks particularly with regard to derivatives, nonperforming loan provisioning, and capital adequacy. Also, a multitude of technological changes are necessary for suave implementation of IFRS. There would be greater emphasis on making huge disclosures by banks. Because of these requirements, banks should start working on this 
right now. Adoption of full fledged FVA by banks certainly would give rise to some supervisory concerns. One amongst such significant concerns relates to extending fair value as a measurement basis for illiquid financial instruments for which there are no apparent market prices. Notwithstanding several debates, there is a general consensus that the clock should not be turned back on FVA just to address the issue of temporary market illiquidity.

\section{CONCLUSION}

Although FVA methods, entail the banks to value their assets employing current market prices they can accentuate downward price spirals. In view of this, the approach could be that, the rules should permit banks and financial institutions with traded assets to allocate "valuation reserves," that grow up to reflect over-valuations during upswings and serve as a good buffer against any reverting to lower values during downturns. Correspondingly, Values of some assets offered as collaterals move with the economic cycle. In such cases more scope is desirable in the accounting rule book to permit the reporting of conservative valuations, based on futuristic and quantifiable indicators. While allowing the banks to use their own suppositions, the relevance of the obtainable market data, such as, default rates, prepayment speeds and interest rates etc. should not be ignored.

To conclude, Fair Value Accounting standard is a good first step towards creating enhanced guidance for the assessment of fair values. Nevertheless, a great deal of work is required to be done in order to make fair value estimates more reliable, provable, and auditable. Credit portfolio managers are required to be aware of these movements and as to how they will affect their understanding of companies that they evaluate. In the context of credit risk 
management Credit derivatives are proved to be useful. However, they raise thorny accounting issues. While FVA option is one promising approach to address this issue, furtherance of this alternative accounting method should progress in an objective and reasonable approach to ensure that it results in fair developments in accounting practices.

\section{References}

Barth, M, (2004), Fair Values and Financial Statement Volatility, In: The Market Discipline Across Countries and Industries, Claudio Borio, William Curt Hunter, George G Kaufman, and Kostas Tsatsaronis (Eds), Cambridge, Massachusetts: MIT Press

Benston, G. J, (2008), The shortcomings of fair-value accounting described in SFAS 157, Journal of Accounting and Public Policy 27, 101-114.

BIS, (2005), Fair Value Accounting, BIS Winter 05_fair.pdf, p26-29, www.bis.org.bcbs

Christian Laux, Christian Leuz, (2009), The Crisis of Fair Value Accounting: Making Sense of the Recent Debate, Working Paper No. 33, Initiative on Global Markets, The University of Chicago, Booth School of Business

Cifuentes, R., G. Ferrucci, and H.S. Shin, (2005), "Liquidity risk and contagion", Journal of the European Economic Association 3: 556-566.

G20 Working Group 1, (2009), Enhancing Sound Regulation and Strengthening TransparencyFinal Report, RBI, Monthly Bulletin, May 2009

Guerrera, F. \& Hughes, J, (2008), Top banks call for relaxed write-down rules. Financial Times, May 21, 2008.

IASB Advisory Panel, (2008), Measuring and disclosing the fair value of financial instruments in markets that are no longer active, October.

Institute of International Finance (IIF), (2008), Final report of the IIF committee on market best practices: principles of conduct and best practice recommendations.

Landsman, W.R,( 2006), "Fair value accounting for financial instruments: Some implications for bank regulation." BIS Working papers No. 209

Penman, S. H, (2007), Financial reporting quality: Is fair value a plus or a minus? Accounting and Business Research Special Issue: International Accounting Policy Forum, 33-44

RBI, (2009), Report on Trend and Progress of Banking in India-2008-09, Reserve Bank of India 
(RBI), Mumbai, available at www.rbi.org.in

Report of the Committee on Financial Sector Assessment (CFSA), (2009), Volume-1, Executive Summary, Government of India, Reserve Bank of India, India available at www.rbi.org

Ryan, S.G, (2008), Accounting in and for the subprime crisis. The Accounting Review 83, 16051638.

Tweedie, D, (2008), as quoted in the minutes of evidence taken before treasury committee banking crisis, November 11, uncorrected evidence 1167 